\title{
A Comparative Study of Space and Time Transference of Main Characters In British and Armenian Fairy Tales
}

\author{
Prof. Yelena Mkhitaryan ${ }^{1}$, Lusine Madatyan ${ }^{2}$ \\ Faculty of Foreign Languages, Armenian State Pedagogical University after Kh. Abovyan, Armenia
}

\begin{abstract}
The paper presents a comparative study of space and time transference of main characters in British and Armenian fairy tales, with pointing out convergent and divergent features of expressing these notions in a folkloristic text. The analysis shows that similarities prevail over differences. In both British and Armenian fairy tales spatial transference takes priority over the temporal one, when the main characters' adventures or heroic deeds are presented; temporal transference is more common when evil deeds are described, especially the ones that happen at night. Besides, tragic and evil events are likely to take place more in enclosed areas than in open places. The numbers three and seven occurring in British and Armenian fairy tales have the same symbolic meanings. The differences concern the numerical indication of time points usually observed in British fairy tales and the presentation of the narrative space, which is somewhat different in view of the diverse country landscape of England and Armenia. While the opening formulas are almost identical, the closing formulas in Armenian tales reveal some differences, ending with a reward for the listener and teller of the fairy tale as well as with blessings and behests directed to the listener.
\end{abstract}

Keywords: fairy tale, main character, space transference, time transference, narrative space, folkloristic text 


\section{3rd International Academic Conference on Research in SOCIAL SCIENCES \\ 10- 12 June, 2021 \\ Berlin, Germany}

\section{Introduction}

\subsection{Space and time relationship (a general review)}

Events usually take place in space and time, each having its specific role in reflecting the objective reality. Each event requires three space dimensions and a time for its description, so "time and space taken together form the space-time continuum” (Tenbrink 2007:25). It is difficult to describe an event without mentioning the time and place of its occurrence; even if one is absent, the other is likely to presuppose it. "All orientation in time presupposes an orientation in space and vice versa" (Hoffmann 2005:269.) In physics too, space-time is regarded as a single concept that recognizes the union of space and time, first proposed by the mathematician Hermann Minkowski in 1908 as a "way to reformulate Albert Einstein's special theory of relativity" (Encyclopaedia Britannica). Time and space are the most fundamental categories of human cognition, and they find their indication in all human languages, often functioning as analogous concepts. Though space and time constitute a whole, they differ in some aspect. According to the adherents of classical philosophy, one of the most essential differences between space and time is that space is reversible, whereas time is not. "Someone always marching straight ahead into the universe could end up back where s/he started" (Stachel 2005: 46). That time is irreversible is illustrated by the metaphorical comparison made by Th. Kitching: "It's like cracking an egg to make an omelette once it spreads out and fills the frying pan, it will never go back to being egg-shaped." (Kitching 2016). But the sciences prove that there is nothing absolute or frozen in nature and that time too can be seen as moving backwards. "The entire history of the universe would repeat itself after a finite time had elapsed", says J. Stachel (ibid: 48). Kitching notes that "while we take for granted that time has a given direction, physicists don't: most natural laws are 'time reversible,' which means they would work just as well if time was defined as running backwards" (Kitching 2016). In this sense, we can but agree with Kujundzic, who argues that "there is no dominant notion of space and time in our society at present and instead presents possible interpretations offered by the theories of Newton, Einstein, Leibnitz, Whitehead, and Lefebvre” (Kujundžić 2020). Moreover, scientists claim that "the space-time structures no longer form a fixed stage, on which the drama of matter and fields are enacted; space and time have become actors in the drama" (Stachel 2005: 45). Indeed, the notions of space and time are frequently used symbolically to indicate various 


\section{3rd International Academic Conference on Research in SOCIAL SCIENCES \\ 10- 12 June, 2021 \\ Berlin, Germany}

events and happenings of the world scope. Let us recall the following events: The Year1066 (The Battle of Hastings), The Year 1929 (The Wall Street Crash, USA), Hiroshima and Nagasaki (bombing, 1945), The Year 1914 (the beginning of the WWI), Sochi 2004 (Winter Olympics). Here, the dates and names of places represent events of great significance and importance (given in brackets). Thus, we see that space and time serve not only as mere settings or prerequisites for events to take place but constitute the concrete, tangible elements of their description. That space and time are close in meaning is evident in the following expressions in which these terms function as analogous words: He fell asleep in the space of a few minutes; Several tragic events happened in the space of ten days; The job holder will be on probation for the space of six months (Oxford Collocations Dictionary 2005).

\subsection{Space and time in fairy tales}

The well-known Russian literary critic M. Bakhtin holds that the basic elements of any folkloristic text are space and time, and he uses the term chronotope, defining it as "the intrinsic connectedness of temporal and spatial relationships that are artistically expressed in literature" (2011: 84). He emphasizes that the study of chronotopes in fairy tales is an indispensable prerequisite of profound comprehension of the content of a folkloristic text (ibid). It is worth mentioning that the linguist focuses his attention on time regarding it more dominant in fairy tales than space. He notes that time depicted in fairy tales makes space more measurable and comprehensible and therefore it should be an object of most extensive and intent examination (ibid). The same approach is maintained by W. Nicolaisen, who also claims that "the narrative gives priority to time" (1988: 360). On the contrary, another prominent Russian linguist V. Propp holds that space is more central, as it is associated with the deeds and adventures of the main character. He writes, "Events in fairy tales take place first of all in space just like in real life" (Wagner 2009). It is evident that time and space cannot function as real categories in fairy tales. They are relevant while the characters of fairy tales exist and their adventures or deeds are in progress. When the fairy tale ends, the characters cease existing, so do their deeds. This is congruent with Leibniz's thesis that "space is not something substantive but is merely the order of coexisting things; similarly, time is merely the successive order of things" (Barbour 1982: 251). Historically, this view was opposed to Newton, who maintains that a distinction between his absolute concepts and Leibniz's relational 


\section{3rd International Academic Conference on Research in SOCIAL SCIENCES \\ 10- 12 June, 2021 \\ Berlin, Germany}

concepts becomes meaningful only at the level of dynamical theories of motion (ibid.). Thus, motion, movement appears to be the most significant element in the spatial and temporal structure of any event.

Bakhtin notes that the plot of a fairy tale includes the transference of the hero/heroine in space as an indispensable feature of a folk text (ibid. 98). B. Bettelheim also recognizes "the importance of space and spatial transference in fairy tales by identifying the protagonist's departure from home as the first step on the symbolic journey of self-discovery and growth" (Kujundžić 2020: 30). It is worth mentioning that transference is one of the six stages that Propp's thirty-one tale functions fall into alongside with preparation, complication, struggle, return and recognition (Propp 2009: 111). We think it is ontologically logical: a prehistoric man had to struggle against natural elements to support his life - he had to be active and move from place to place in search of food and shelter. As far as fairy tales are concerned, we observe that the main characters move on a space/time axis from one point to another point to accomplish the tasks they set before themselves. The spatial and temporal transference of folk characters is the object of our study. The main aim of our investigation is to examine how the notions of space and time transference of main characters are actualized in British and Armenian folk texts, with pointing out convergent and divergent features of expressing them. The task is very important and necessary since there appears to be no such research done in reference to British and Armenian fairy tales (Briggs 1967; Swann 1995; Tolkien 2013; Rahman 2012; Likhachev 2016; Lebedeva 2015; Liabenov 2014). In this respect we can mention N. Kujundzic' dissertation entitled 'Narrative Space and Spatial Transference in Jacob and Wilhelm Grimm's Fairy Tales" (Kujundžić 2020). As is seen from the title, the author has chosen the German fairy tales as an object of her study and focuses only on spatial transference. Our paper deals with space and time transference of the main characters, focusing on similarities and differences of their expression in British and Armenian fairy tales. We have chosen ten British and ten Armenian fairy tales for our study (the complete list is given in REFERENCES).

\section{Spatial and temporal transference of main characters in British and Armenian fairy tales}

\subsection{Spatial transference}

Events in a fairy tale generally develop in two directions: one direction shows the life of the main characters from the outset and continues through their heroic deeds during which they pass a great 


\section{3rd International Academic Conference on Research in SOCIAL SCIENCES \\ 10- 12 June, 2021 \\ Berlin, Germany}

distance to achieve their aims, overcoming plenty of misfortune and deprivations and, finally, after defeating the villain, return home, usually happy and victorious. The second direction is that of other characters of a fairy tale, who can be kind or evil and they also participate in all kinds of events helping the main characters or, conversely, fighting against them, preventing them from accomplishing their aims. In both cases the main characters operate according to the same scheme. The traditional model of main characters' transference in a fairy tale looks like: the main character's home - the outer world - his home. This can be presented by the following scheme, where $\mathrm{S}$ is the home of the main character and small $\mathrm{s}$ is the space object that the folk character has to overcome during their transference.

$$
\mathrm{S} \longrightarrow\{\text { outer world (ow) }\} \longrightarrow \mathrm{S}
$$

According to the scheme, the main characters are supposed to reach a certain space point during their deeds or adventures, after which they return to the same space point. This is congruent with the philosophical thesis that space is reversible: $\mathrm{S}=\mathrm{S}$.

This model can be said to be universal: fairy tales of many nations, including British and Armenian tales, practically follow this pattern in which individual parts of space are combined to create the spatial complex (Zoran 1984: 322-323). The description of the outer world (ow) depends largely on the size of a fairy tale: the longer the fairy and tale is, the vaster the outer world is. The beginning and the end of main characters' transference are usually preserved; the difference affects the outer world, which can be presented by various space units that the main characters have to pass through to accomplish their tasks. Let us consider the English fairy tale "The Brown Bear of the Green Glen".

A king was losing his sight and his young son set out to look for water to cure his father. On his way to the intended place, he saw his two elder brothers in the town. Continuing his way, he came to the forest. He saw a bear in the green glen. He wrestled with a giant. He came to the Green Island to find the water for his father. He came back to the town where his brothers tried to steal the water from him. He returned home with the water and his father recovered. We can illustrate the young son's space transference by the following model: 


\section{3rd International Academic Conference on Research in SOCIAL SCIENCES \\ 10- 12 June, 2021 \\ Berlin, Germany}

His home $\longrightarrow$ town $\longrightarrow$ forest $\longrightarrow$ glen $\longrightarrow$ the Green Island $\hookrightarrow$ town $\longrightarrow$ his home

Graphically it can be designated by the following scheme

$$
\mathrm{S} \longrightarrow\left\{\mathrm{s}_{1} \longrightarrow \mathrm{s}_{2} \longrightarrow \mathrm{s}_{3} \longrightarrow \mathrm{s}_{4}\right\} \hookrightarrow \mathrm{s}_{1} \longrightarrow \mathrm{S}
$$

in which OW includes $\mathrm{s}_{1}, \mathrm{~s}_{2}, \mathrm{~s}_{3}, \mathrm{~s}_{4}$ indicating each space unit the main character passes through during his journey. The sign $\hookrightarrow$ designates the hero's way back to his home. It is worth mentioning that the narrator does not repeat all the space objects that the hero passes on his way back home, singling out only those ones that the hero's actions call for $\left(\mathrm{s}_{1}\right)$.

As we see, the outer world of the hero is full of dangerous deeds and he has to fight his foes, and complete the tasks set before him, and ultimately, comes home as winner. We also note that all events take place in the open area, which is a proper place for various deeds and combats.

As we mentioned earlier, events in a fairy tales develop in two directions: one is the direction of actions taken by the hero/heroine and the second by other, often negative characters of a tale.

Now we will discuss the Armenian fairy tale "The Handless Girl". The brother had a sister, whom he loved dearly, but his wife was envious of her beauty and treated her most cruelly, accusing her of all kinds of crime the poor girl had not committed. Ultimately, the sister was punished, had her hands cut off and sent to a forest. She had to pass across valleys, canyons, a forest where she found a hollow in a tree and thus was saved. Once the passing prince saw her, fell in love with her and took her to the castle and married her. She gave birth to a wonderful golden-haired son. Her happiness did not last long. Soon she again found herself under assault from her wicked sister in-law. The woman's suffering started again with a more dreadful and destructive vigor. Now she had to suffer with her child, passing through a dark forest, deep canyons and uninhabited valley and finally, the well. Bending over the well she drops her child accidentally into the well. An old man passing by advised her to take her child out of the well, which she did and she got her hands back. Meanwhile the prince was looking for her everywhere and at last found her at a caravan site and brought her and their child to his home. The space transference of the heroine can be drawn this way: 


\section{3rd International Academic Conference on Research in}

Her brother's home $\longrightarrow$ forest $\longrightarrow$ valleys $\longrightarrow$ mountains $\longrightarrow$ canyons $\longrightarrow$ the tree hollow $\longrightarrow$ the castle $\hookrightarrow$ forest $\longrightarrow$ canyons $\longrightarrow$ mountain $\longrightarrow$ uninhabited valleys $\longrightarrow$ well $\longrightarrow$ caravan site $\longrightarrow$ the castle

Graphically it looks like:

$$
\mathrm{S} \longrightarrow\left\{\mathrm{s}_{1} \longrightarrow \mathrm{S}_{2} \longrightarrow \mathrm{S}_{3} \longrightarrow \mathrm{S}_{4} \longrightarrow \mathrm{S}_{5} \longrightarrow \mathrm{S}_{6} \rightleftarrows \mathrm{S}_{5} \longrightarrow \mathrm{S}_{4} \longrightarrow \mathrm{S}_{3} \longrightarrow \mathrm{S}_{2} \longrightarrow \mathrm{S}_{5} \longrightarrow \mathrm{S}_{7}\right\} \rightarrow \mathrm{s}_{6}
$$

From the scheme we see that on her way back $(\hookrightarrow)$ from the castle $\left(\mathrm{s}_{6}\right)$ she repeats her route and finds a new space object: the caravan site ( $\left.\mathrm{s}_{7}\right)$; she does not return to $\mathrm{S}$ (her brother's home), but stays at the castle ( $\left.\mathrm{s}_{6}\right)$.

The other plot line is related to her brother's wife. This wicked woman stays home, only once changing the place of her residence (S) for a caravan site $\left(\mathrm{s}_{7}\right)$. She does all her evil actions against her husband's sister in a closed area. She pursues her sister- in- law, inflicting all kinds of cruelties and misfortune on the wretched woman. Now she lives in the caravan site belonging to the prince. The wicked woman traces the poor woman with her child everywhere. It so happens that the prince's parents sent a congratulatory letter to their son in connection of his son's birth. The wicked woman changes the content of the letter informing the prince of a birth of a dog-like child. She also changes the prince's answer in which the prince "demands" that the woman with her son immediately leave the castle, which his parents promptly, though unwillingly, do.

Thus, we see that the wicked woman committed all her crimes within two enclosed areas: her home $(\mathrm{S})$ and the caravan site $\left(\mathrm{s}_{7}\right)$. The space transference is shown graphically by the scheme:

$$
\mathrm{S} \longrightarrow\left(\mathrm{S}_{7}\right)
$$

We might conclude that tragic events take place in enclosed areas more frequently than in open areas. Open areas are more likely to be arenas for adventures and brave deeds. The same pattern of spatial transference can be seen in the Armenian Fairy tale "Zangi-Zrangi", the English tales “The Young King of Easaidh Ruadh", "Conall Cra Bhuidhe” and others.

Space may be relational. The main characters can transfer in another world different from the world they live in. For example, in "The Recovered Bride" the hero sees a dream in which he is instructed to follow a certain plan, which would help overcome certain difficulties and thus change the situation in his favour. The hero acts as he is advised and wins the battle.

It is worth mentioning that not all fairy tales have a happy end. For example, in "The Fairy's Midwife" the midwife who was summoned to attend at the birth of a fairy mother was punished 


\section{3rd International Academic Conference on Research in SOCIAL SCIENCES \\ 10- 12 June, 2021 \\ Berlin, Germany}

by the wife's wicked husband whom the midwife accused of stealing the ointment. The same unhappy end is recorded in the Armenian fairy tale "Barikendany" (Shrove Tuesday). The foolish and ingenuous wife and husband who used to quarrel with each other lost their butter and rice because of being cheated by a stranger. Interestingly, in both fairy tales the space narrative is limited by the enclosed area as the actions of the main characters do not need vast land or distance. When comparing the models of spatial transference of the folk characters in British and Armenian fairy tales we see that similarities prevail over differences. Thus, we see that Propp was right when stating that "it doesn't matter if stories vary in different times and different places due to cultural differences, since it is still the same story structurally" (2009: 23). In both British and Armenian fairy tales spatial transference takes priority over the temporal one, when the main characters' adventures or good deeds are presented; besides, tragic and evil events take place more in enclosed areas than in open places. Similar are also the stretches of space that the characters have to pass to achieve their aims. Differences are as follows: when the space objects are enumerated - forests, valleys, gorges, mountains, hills - the latter is not mentioned in Armenian fairy tales as the space narrative in them does not contain the hill as a characteristic relief of the Armenian country, which is geographically true in view of its high- mountainous character. The spatial objects serving as means of salvation are different: in English tales it is the top of the tree ("The Brown Bear of the Green Glen"), while in Armenian fairy tale it is the hollow of the tree ("The Handless Girl").

\subsection{Temporal Transference}

\subsubsection{The general model of temporal transference}

Folk characters change their position not only in space but in time as well. The temporal transference of main characters in a fairy tale has its specific features. Propp (2009), Meletinsky (1958), Nekhlyudov (1971) distinguish two aspects in the temporal structure of a fairy tale: dynamic and static. It should be noted that aforementioned folklorists refer this classification to spatial organization of a fairy tale, but we think it may be applicable to temporal transference as well. Dynamic episodes are characterized by the constant intensive development of the plot. The static aspect is reflected in indefiniteness, absence of concrete time and events. Likhachev (2016) claims that time in a fairy tale moves only in one direction and never goes back. Bakhtin opposes to this, saying that time is always found to run forward or backward (ibid.). Indeed, the basis of 


\section{3rd International Academic Conference on Research in SOCIAL SCIENCES \\ 10- 12 June, 2021 \\ Berlin, Germany}

the plot development of a fairy tale is the succession of events that takes its start from the indefinite time, or eternity, moves towards relatively definite time points and then returns to indefiniteness, eternity (Lebedeva 2015). To accomplish their aims the main characters have to go through a series of various adventures or brave deeds that take place at certain time stretches. This temporal transference of a hero/ heroine may be illustrated by the following formula:

$\mathrm{T} \longrightarrow\{$ time stretches $\} \longrightarrow \mathrm{T}$, in which $\mathrm{T}$ designates the beginning of the fairy tale. The end of a fairy tale is marked by the return of $\mathrm{T} C \mathrm{~T}$.

The different time stretches that the fairy-tale characters act at, performing their deeds or undertaking various adventures are indicated by $t_{1}, t_{2}, t_{3}, t_{4} \ldots$. This is shown by the following scheme:

$$
\mathrm{T} \longrightarrow\left\{\mathrm{t}_{1}, \mathrm{t}_{2}, \mathrm{t}_{3}, \mathrm{t}_{4} \ldots\right\} \longrightarrow \mathrm{T}
$$

We see that the philosophical thesis that time, unlike space, is irreversible becomes irrelevant in fairy tales. The characters start their deeds at $\mathrm{T}$ (unreal time) and end at $\mathrm{T}$ (unreal time).

\subsubsection{Beginning of a fairy tale}

The unreal, indefinite time in fairy tales is expressed by the traditional opening and closing formulas that show the time points at which the events take place or come to an end. Opening formulas are almost identical in British and Armenian fairy tales (Nicolaisen 1988; Balayan 2010; Khemchyan 2010): British- Once upon a time; There was ... once; Many-many years ago; Longlong time ago there was/lived; In times gone by. Armenian- There was or was not (Linum e chi linum); There lived or did not live (Yeghel e chi yeghel); In times gone by (Zhamanakov).

- There was an old soldier once, and he left the army. (TS)

- Once upon a time there was, in this celebrated town, a Dame Somebody. (FM)

- Jamanakov linum en, chen linum mi quyr u mi akhper en linum. (KA) (In times gone by there was or there was not a brother and a sister.)

- Yeghel e, chi yeghel mi tagavor. (AB) (There was, there was not a king.)

The time required for the achievement of the aim is expressed by different time units. Every new event or adventure starts with a new time stretch $\left(t_{1}\right)$ : British - One day, On a day of days, Once; Armenian -Mi or (One day), Mi angam (Once).

- They were one day sauntering by the side of the loch, and there came a beast 


\section{3rd International Academic Conference on Research in SOCIAL SCIENCES \\ 10- 12 June, 2021 \\ Berlin, Germany}

more wonderfully terrible than the other. (SM)

- One day, it being observed that William was absorbed in deep thought, his courtiers ventured to inquire the cause of such profound abstraction. (LSC)

- Mek or ays tagavori vorsordnerits meky galis e nra mot ev asum e. (AB) (One day one of the king's hunters comes to him and says.)

- Mek angam zbosnelu ein durs yekel getapy. (AB) (Once they went out hunting to the bank of the river.)

In some cases, the time stretch may become definite when supplemented by the indication of the numerical time point. But even so the time point lacks the absolute exactness, which is denoted by the presence of the approximator (about). It is worth mentioning that this is generally observed in British tales.

- One night about twelve o'clock in the morning. (FM)

The second day of the event $\left(\mathrm{t}_{2}\right)$ is expressed by: British - The following day; The next day; A short time after this; Soon after; Morrow (next day); Armenian -Hajord ory (The following day), Myus ory (The next day).

- On the next morning he went on further with them. (SM)

- On the morrow they went away, and there was no question at all but that the hero would save the king's daughter. (SM)

- Myus ory hayry Tatukhin patver tvav ev asats. (ZZ) (The next day Tatukgi's father ordered him, saying...)

\subsubsection{The middle of the fairy tale}

When the hero/heroine's succeeding deeds or adventures are described, time indicators $\left(t_{3}, t_{4}\right.$, $t_{5} \ldots$ ) denote not only time points, but also a longer period of time, i.e. time intervals, which may be definite, indefinite or cyclic.

1) Time point (Tp)

- The gentleman came well early in the morning. (TS)

- "Meet me to-morrow at eleven in yonder church," and she left him there. (WS)

- Yereq tarin lratsav te che hents en gishery kgam dzez harts ktam. (KhDz)

- Shat lav, yes hents vaghy karogh em ch'anaparh ynknel. (A1) (All right, I can set 


\section{3rd International Academic Conference on Research in SOCIAL SCIENCES \\ 10- 12 June, 2021 \\ Berlin, Germany}

off just tomorrow.)

As we have mentioned, events take place in two directions: one is the hero's adventures, the other is the negative characters' behavior. It is worth mentioning that when the wicked characters' actions take place, time indication prevails over space transference and it is basically specified by Tp. On the contrary, in case of the hero's deeds space transference becomes dominant. Bad deeds in fairy tales often take place at night. No surprise, all the evil deeds that the wicked woman commits ("The Handless Girl") take place at the dark time of the day. The formula of the woman's temporal transference is illustrated by the following formula:

Once $\longrightarrow$ next time $\longrightarrow$ at night $\longrightarrow$ at the sunset $\longrightarrow$ at night $\longrightarrow$ in the evening $\longrightarrow$ in the middle of the night $\longrightarrow$ at night $\longrightarrow$ at this time of night. The time transference of the female character is designated in the following way: $\mathrm{T} \rightarrow\left\{\mathrm{Tp}_{1} \rightarrow \mathrm{Tp}_{2} \rightarrow \mathrm{Tp}_{3} \rightarrow \mathrm{Tp}_{4} \rightarrow \mathrm{Tp}_{5} \rightarrow \mathrm{Tp}_{6} \rightarrow \mathrm{Tp}_{7} \rightarrow \mathrm{Tp} 8\right\}$ We see that the word night is repeated seven times. The same picture can be observed in "The Sea-Laden", when the hero's fighting against the giants can be presented by the following time scheme: at the mouth of night $\longrightarrow$ this night $\longrightarrow$ one night $\longrightarrow$ on the morrow when the time was nearing $\longrightarrow$ one night, on the morrow $\longrightarrow$ about the mouth of night

\section{2) Time interval (Tint)}

a) definite Tint

- So a year passed, and Halloween came round again. (JFYL)

- Gnu men mi tari, yerku tari, yereq tari, voch teghn en imanum, voch teghekutyun. (KA) (They had been walking one year, two years, three years, they knew neither the place nor got any information).

\section{b) indefinite Tint}

- She wrote, but weeks passed, and she received no answer. (JFYL)

- Sra vra antsav tasy tari kam mi qich aveli kam pakas, ayd Astvats gite. (ZZ) (After these ten years or so passed, knows God how long.)

- Orer antsan, mer tgherqy cherevatsin. (AB) (Days passed; our young men did not turn up) 


\section{3rd International Academic Conference on Research in SOCIAL SCIENCES \\ 10- 12 June, 2021 \\ Berlin, Germany}

c) cyclic $\mathbf{T}$

- Each Saturday night he came round, he poured his wages into her lap. (JFYL)

...... the hunting and fishing went on afterwards, and there were feasts of venison, and wild boar, and drinking of wine and mead in the evenings ... (TAW)

- Ayspisov, taretstari shatanum er vranneri tivy. (A2) (Thus, the number of tents increased year by year.)

- Orakan mi qani dzukn e ashkhatum, tun berum, nranov aprum en inqn u kniky. (KhDz) (He catches a few fish daily, brings them home, he and his wife live on them.)

\subsubsection{The ending of fairy tales}

The end of fairy tales is expressed by the traditional closing formulas which to some extent are different in British and Armenian fairy tales. The most popular closing formulas in British fairy tales are as follows: They were happy ever since; They lived happily ever after; They were lucky and well pleased after that, etc. Very often the end of the fairy tale is crowned with marriage or accomplishment of the aims.

- And they lived happily ever afterwards. (EMD)

- If they have not died since then, they are alive to this very day. (SM)

- There was a splendid wedding. And they all lived in the grand Dublin house. (JFYL)

In Armenian fairy tales the end is also marked by the hero's marriage or accomplishment of certain aims. As different from the British tales, the listener of an Armenian fairy tale is usually rewarded, thus becoming an active participant of folk telling-listening process. The reward may be in the form of some object (for example, an apple) or blessing. The end of the tale may also include behests addressed to the listener.

a) an apple

- Ays harsaniqumy, inchpes amen heqiati harsaniqum, nujnpes yereq khndzor vayr ynkan ughghaki yerknqits, miayn ays angam hndzornery asoghi ev lsoghi hamar chen. $(A B)$ (During this marriage as in every fairy-tale marriage three apples dropped from the haven, but this time the apples were not meant for the teller and the listener.) 


\section{3rd International Academic Conference on Research in SOCIAL SCIENCES \\ 10- 12 June, 2021 \\ Berlin, Germany}

b) blessing

- Nranq hasan irants murazin, duq el hasneq dzer murazin. (ZZ)

(Their dreams came true. So may your dreams come true.

- Tog im hovanavorutyuny liuli taratsvi qo zharangneri ev qo azgi vra. (HJ) (Let my favor extend to all your successors and your nation.)

\section{c) behests}

- Lavutyun ara u tekuz dzury gtsi` chi korchi. (KhD) (Do the good and throw it into the water, it will come back to you)

- Charn ayntegh, barin aystegh. (Y)e (Let the evil go and the good stay here)

- Yereq kndzor vayr ynkan ughghaki yerknqits meky`havati ev qadzutyan hamar, yerkrordy huso ev araqinutjan, ev errordy`siro ev uzhi hamar. $(A B)$ (Three apples fell from the haven: one for faith and bravery, the second for hope and chastity and the third for love and power.)

Many Armenian fairy tales end not only by extolling the main character's deeds but also punishing the evil, thus enhancing the sense of justice in listeners.

- Yeghegnuhun taran palaty, yot or, yot gisher harsaniq arin, isk boshayin kapetsin mi dziu pochits ev, qereqar talov, satketsretsin. (Y) (Yeghegnuhi was taken to the castle, the marriage lasted seven days and seven nights but the wicked woman was tied to the horse's tail and killed with stones.)

- Isk char harsin kapum en kataghi dziu pochin u bats en toghnum ardzak dashterum. (KA) (The evil woman was tied to the mad horse's tail and let of to the fields)

\subsubsection{Numbers tree and seven in fairy tales}

As is known, some numbers in fairy tales are ritual related to religious concepts and are found in many European and Eurasian fairy tales. Let us take the numbers three and seven, which we often come across in British and Armenian fairy tales. People attribute the number three (Tint) to many ideas of religious nature. S. Buvala says that the number three is related to the central tenet of Christianity, i.e. the concept of the Trinity: The Father, the Son and the Holy Spirit. But he also 


\section{3rd International Academic Conference on Research in SOCIAL SCIENCES \\ 10- 12 June, 2021 \\ Berlin, Germany}

produces another explanation, which includes "Jesus being visited by three kings at his birth and his three days in the tomb before his resurrection" (Buvala 2017: 2). We think both the explanations are reliable and acknowledged by many folklorists. Below are examples with the number three in British and Armenian fairy tales.

- As soon as three years have passed, I will come to you that very night and ask you a question. (SM)

- When thy son is three years of age, and thou thyself wilt get plenty of fish after this. (SM)

- Yereq amis chantsats`arseni vra voch mi vayrenutyan nshan chmnats, aylev yerevats, vor na shat shnorhakal e ev imastun. (HJ) (Scarcely had three years passed when Arsen got rid of any sign of wildness and became very gifted and wise.)

The number seven (Tint) symbolizes seven days of the week, seven sacraments, seven days of creation, seventh day Adventism (Liabenov 2014). In the Hebrew/Jewish tradition seven is very powerful, as in the days of creating, and God resting on the seventh day (Mellor 2019). Ancient Greeks regarded the number seven sacred and perceived it a symbol of absolute perfection (Harutyunyan 2014: 75).

- They made a great rich wedding that lasted seven days and seven years. (BBGG)

- Heto Odzamanukin u Arevahatin yot or, yot gisher harsaniq en anum. (A2)

(Afterwards Odzamanukin and Arevahatin arranged a wedding which lasted seven days and seven nights)

Interestingly, the number seven refers to the same occasion (marriage) in British and Armenian fairy tales, which testifies to the fact that some aspects of culture may be of universal character. However, while the number seven is recorded in almost all Armenian fairy tales, describing the wedding, this is not the case with British fairy tales, in which even the number twenty may come along.

- And a wedding of twenty days and twenty nights was made for the young couple. (TCC) 


\section{3rd International Academic Conference on Research in SOCIAL SCIENCES \\ 10- 12 June, 2021 \\ Berlin, Germany}

\subsubsection{Indirect temporal indication}

Temporal information may be obtained indirectly through spatial indication, which once again emphasizes the functional connection between the notions of space and time. Consider the following extract from "Jamie Freel and the Young Lady".

- Jamie mounted, and his steed rose with him into the air. He was presently flying over his mother' cottage, surrounded by the elfin troop, and on and on they went over bold mountains, over little hills, over the deep Lough Swilley over towns and cottages. It seemed to Jamie that they flew all round Ireland before they got to Dublin.

We see that the time duration can be measured by the enumeration of space objects that the hero (Jamie) has to pass through to achieve his aim (reaching Dublin). This example testifies to another fact too: when the hero's deeds take place in the open area temporal information concedes to spatial representation.

- Her man was mournful, tearful, wandering down and up about the banks of the loch. (JFYL)

Here we see the transformation of time triggered by the spatial transference of the folk main character (wandering up and down about the banks of the loch) takes a good deal of time. Similar transformation is observed in the Armenian fairy tales as well. Consider the following extract from "The Handless Girl":

- Espes, krnaty, men-menak taparum e Lusiky anbnakan antarnerum. Shat tapareluts tpern u pshery hagi shorery tanum en, mnum e tklor. (KA) (So the handless girl was roaming in the forest. Her clothes were torn by bushes and thorns and she was naked now.)

There is no exact time indication in this example, but the mention of the heroine's clothes being torn by bushes and thorns and as a result her becoming naked testify to a long period of her misery and deprivation. 


\section{3rd International Academic Conference on Research in SOCIAL SCIENCES \\ 10- 12 June, 2021 \\ Berlin, Germany}

\section{Conclusion}

The comparative analysis of spatial and temporal transference of main characters in British and Armenian fairy tales shows that similarities prevail over differences. In both British and Armenian fairy tales spatial transference takes priority over the temporal one, when the main characters' adventures or their deeds are presented; temporal transference is more common when the evil deeds are described, especially the ones that happen at night. Besides, tragic and evil events take place more in enclosed areas than in open places. Open areas are more likely to serve as arenas for brave deeds and adventures. In some cases, temporal information is obtained through space indication. The numbers three and seven are both used in British and Armenian fairy tales, having the same ritual meanings. The following differences are recorded: while the opening formulas are almost identical, the closing formulas in Armenian tales are different to some extent. They include the listener as an active participant of the story telling-listening process and is often rewarded with some object or given blessings and behests. Many Armenian fairy tales end not only by extolling the main character's deeds but also by punishing the evil. Besides, when the space objects are enumerated - forests, valleys, gorges, mountains, hills - the latter is not mentioned in Armenian fairy tales as the space narrative does not contain the hill as a characteristic relief of the Armenian country, which is geographically true in view of its high- mountainous character. According to the temporal information that the fairy tales convey, the numerical indication of time is more typical of British fairy tales. The spatial objects serving as means of salvation can sometimes be different: in British fairy tales it is the top of the tree, whereas in Armenian fairy tales it may be the hollow of the tree. 


\section{3rd International Academic Conference on Research in SOCIAL SCIENCES \\ 10- 12 June, 2021 \\ Berlin, Germany}

\section{References}

Bakhtin M. 2011/1937. Forms of Time and Chronotopes in the Novel. The Dialogic Imagination. Four Essays. pp. 84-258. (in Russian)

Balayan V. 2010. Opening Formulas in Armenian and British Folktales. Yerevan: Voske Divan, vol. 2, pp. 85-90. (in Armenian)

Barbour J. 1982. Relational Concepts of Space and Time, The British Journal for the Philosophy of Science. The University of Chicago Press: vol.33, pp. 251-274.

Briggs K. 1967. The Fairies in English Tradition and Literature. London: University of Chicago Press.

Buvala K. 2017. Two Plus One is Greater than Three: The Presence of the Number 3 in

Fairytales and Folklore. http://storyteller.net/two-plus-one-is-greater-than-three-thepresence-of-the-number-3-in-fairytales-and-folklore/

Encyclopaedia Britannica. Space-time. https://www.britannica.com/science/space-time Harutyunyan H. 2014. The Epistemological and Axiological Parameters of the Concept Number and the Early Stage of its Genesis. Yerevan: Wisdom, vol. 2, No1. (in Armenian)

Hoffmann G. 2005. The Space-Time Continuum. From Modernism to Postmodernism pp. 269422. https://doi.org/10.1163/9789401202428_007

Khemchyan E. 2010. Opening Formulas in Lori Fairy Tales. Yerevan: Voske Divan, vol.2, pp. 78- 84. (in Armenian)

Kitching Th. 2016. Time, and Why Does It Move Forward?

https://theconversation.com/what-is-time-and-why-does-it-move-forward-55065

Kujundžić N. 2020. Narrative Space and Spatial Transference in Jacob and Wilhelm Grimm's Fairy Tales. University of Turku. Thesis for: $\mathrm{PhD}$

Lebedeva N. 2015. Peculiarities of Spatial-Temporal Organization of a Folk Text. Young Scientist, vol.11, No91, pp.1635-1638. (in Russian)

Liabenov A. 2014. The Significance of the Numbers Three, Four, and Seven in Fairy Tale, Folklore, and Mythology. Grand Valley State University, Scholar Works @GVSU. Likhachev D. 2016. Poetics of Early Russian Literature. https://www.litmir.me/bd/?b=408938. Meletinski E. 1958. The Hero of Folktale. The Origin. 


\section{3rd International Academic Conference on Research in}

https://monoskop.org/images/b/bf/Meletinsky_Eleazar_1969_1974_Typological_Study_of_the_ Folktale.pdf

Mellor B. 2019. Mythology, Philosophy and Theology fascinate me - what makes ushuman? https://summeruniversity.ceu.edu/human-2016

Nekludov S. 1971. Once Again on the Problem of Structural Description of a Fairy Tale. Tartu, pp. 63-91. (in Russian)

Nicolaisen W. 1988. “Once upon a Place, or Where is the World of the Folktale?”. In Albrecht Lehmann and Andreas Kuntz (eds.), Sichtweisen der Volkskunde. Zur Geschichte und Forschungspraxis einer Disziplin. Berlin \& Hamburg: Bietrich Reimer Verlag, pp. 359-366.

Propp V. 2009. Morphology of the Folktale. University of Texas Press. https://monoskop.org/images/f/f3/Propp_Vladimir_Morphology_of_the_Folktale_2nd_ed.pdf Rahman R. 2012. Semantico -Syntactic Features of Oscar Wilde's Fairy Tales. Art. http://prr.hec.gov.pk/jspui/bitstream/123456789/1324/1/2052S.pdf

Stachel J. 2005. Development of the concepts of space, time and space-time from Newton. ToEinstein.https://www.researchgate.net/publication/252881590_Development_of_the_concepts _of_space_time_and_space-time_from_Newton_to_Einstein.

Swann S. 1995. The Fairy Tale: The Magic Mirror of Imagination. New York: Twayne Publishers.

Tenbrink Th. 2007. Space, time, and the use of language: an investigation of Relationships.

Cognitive Linguistics Research. New York: Mouton de Gruyter.

Tolkien J. 2013. On Fairy-Stories. https://www.brainpickings.org/2013/12/05/j-r-r-tolkienon-fairy-stories/

Wagner L. 2009. Morphology of Folk Tale by V. Propp. The USA: University of Texas Press. Zoran G. 1984. Towards a Theory of Space in Narrative. Poetics Today. Vol.5, No2, pp. 309-335.

\section{BRITISH FAIRY TALES}

BBGG: The Brown Bear of the Green Glen. Popular Tales of the West Highlands, vol. 1. J. F. Campbell, 1890. https://www.sacred-texts.com/neu/celt/pt1/pt113.htm\#page_168 CCB: Conall Cra Bhuidhe. Popular Tales of the West Highlands, vol. 1. J. F. Campbell, 1890. 


\section{3rd International Academic Conference on Research in}

\section{SOCIAL SCIENCES}

10- 12 June, 2021

Berlin, Germany

https://www.sacred-texts.com/neu/celt/pt1/pt109.htm\#page_105

EMD: Earl Mar's Daughterh. English Fairy Tales, Joseph Jacobs, 1890

https ://www. sacred-texts.com/neu/eng/eft/eft30.htm

FM: The Fairy's Midwife. Global Grey ebook. E. S. Hartland, 2018

JFYL: Jamie Freel and the Young Lady. Fairy and Folk Tales of the Irish Peasantry. https://www.sacred-texts.com/neu/yeats/fip/fip18.htm

LSC: The Legend of the Sons of the Conqueror. Global Grey ebook. E. S. Hartland, 2018

RB: The Recovered Bride, University of Pittsburgh. D. L. Ashliman, 1996-2020.

https://www.pitt.edu/ dash/abduct.html\#recovered

SM: The Sea-Maiden. Popular Tales of the West Highlands, vol. 1. J. F. Campbell, 1890.

https://www.sacred-texts.com/neu/celt/pt1/pt108.htm

TCC: The Tale of Conal Crovi, Popular Tales of the West Highlands, vol. 1. J. F. Campbell, 1890. https://www.sacred-texts.com/neu/celt/pt1/pt110.htm

YKER: The Young King of Easaidh Ruadh. Popular Tales of the West Highlands, vol. 1. J. F. Campbell, 1890. https://www.sacred-texts.com/neu/celt/pt1/pt105.htm

\section{Armenian Fairy Tales}

ZZ: Zangi- Zrangi (Zangi-Zrangi) Yerevan, Haypethrat. G. Aghayan, 1956.

VH: Vishapin Haghtogh (The Winner of the Devil) Yerevan, Haypethrat. G. Aghayan, 1956.

A1: Anahit. Yerevan, Haypethrat. G. Aghayan, 1956.

A2: Arevamanuky (The Sunny Boy) Yerevan, Haypethrat. G. Aghayan, 1956.

B: Barekendany (Shrove Tuesday) H. Tumanyan.

https://hy.wikisource.org/wiki/\%D4\%B2\%D5\%A1\%D6\%80\%D5\%A5\%D5\%AF\%D5\%A5\%D5 $\% \mathrm{~B} 6 \% \mathrm{D} 5 \% \mathrm{~A} 4 \% \mathrm{D} 5 \% \mathrm{~A} 1 \% \mathrm{D} 5 \% \mathrm{~B} 6 \% \mathrm{D} 5 \% \mathrm{~A} 8$

KA: Krnat Aghjiky (Handless girl) Yerevan, Haypethrat. G. Aghayan, 1956.

https://hy.wikisource.org/wiki/\%D4\%BF\%D5\%BC\%D5\%B6\%D5\%A1\%D5\%BF_\%D5\%A1\%

D5\%B2\%D5\%BB\%D5\%AB\%D5\%AF\%D5\%A8

KDz: Khosogh Dzuky (The Speaking fish) H. Tumanyan.

https://hy.wikisource.org/wiki/\%D4\%BD\%D5\%B8\%D5\%BD\%D5\%B8\%D5\%B2_\%D5\%B1\%

D5\%B8\%D6\%82\%D5\%AF\%D5\%A8

AH: Anban Hurin (Lazy Huri) H. Tumanyan. 
https://hy.wikisource.org/wiki/\%D4\%B1\%D5\%B6\%D5\%A2\%D5\%A1\%D5\%B6_\%D5\%80\%D $5 \% \mathrm{~B} 8 \% \mathrm{D} 6 \% 82 \% \mathrm{D} 5 \% \mathrm{BC} \% \mathrm{D} 5 \% \mathrm{AB} \% \mathrm{D} 5 \% \mathrm{~B} 6$

VK: Voske Karas (Gold Pitcher) H. Tumanyan.

https://hy.wikisource.org/wiki/\%D5\%88\%D5\%BD\%D5\%AF\%D5\%B8\%D6\%82_\%D5\%AF\%D 5\%A1\%D6\%80\%D5\%A1\%D5\%BD\%D5\%A8

HJ: Hnaraget Julhak (The Clever Weaver) Yerevan, Haypethrat. G. Aghayan, 1956.

AB: Aslan Bala (Aslan-Bala) Yerevan, Haypethrat. G. Aghayan, 1956. 